\title{
THE EFFECT OF CURRENT RATIO, DEBT TO EQUITY, SALES GROWTH TOWARDS RETURN ON ASSET AT CONSUMER GOOD COMPANIES LISTED IN STOCK EXCHANGE
}

\author{
Hantono ${ }^{* 1}$ 河 (iD)
}

${ }^{* 1}$ Lecturer at the Department of Accounting, University of Pelita Harapan, Medan, Indonesia

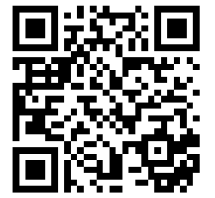

DOI: https://doi.org/10.29121/IJOEST.v4.i6.2020.137

Article Type: Research Article

Article Citation: Hantono. (2020). THE EFFECT OF CURRENT RATIO, DEBT TO EQUITY, SALES GROWTH TOWARDS RETURN ON ASSET AT CONSUMER GOOD COMPANIES LISTED IN STOCK EXCHANGE. International Journal of Engineering Science Technologies, 4(6), 60-70. https://doi.org/10.29121/IJOEST.v 4.i6.2020.137

Received Date: 02 December 2020

Accepted Date: 31 December 2020

Keywords:

Current Ratio

Debt to Equity Ratio

Sales Growth

Profitability

\section{ABSTRACT}

The aim of this research is to establish and evaluate the impact of profitability on consumer goods firms listed on the stock exchange in the period from 2012 to 2016 . The community included in this study, including all consumer products firms. The survey shall be considered using an analytical sampling technique for a limit of 40 firms. The details included in this analysis was supplementary data by collecting the required information from IDX, such as the 2012 - 2016 financial study. The approaches used to evaluate the interaction between the independent variable and the dependent variable are the form of double regression and the method of inference. The outcome indicates that factors - separate variables; current ratio, debt-to-equity ratio, Revenue Development have a significant simultaneous impact on profitability, whereas current ratio, working capital turnover, debt-to-equity ratio have a significant partial effect on profitability.

\section{INTRODUCTION}

The consumer industry business is part of the retail field. The consumer goods industry is thus expected to constantly sustain or raise the income of the business in order to improve the economy of the world. In order to retain and improve the income of the firm, additional expenditure is needed, such as the expansion of the business within and outside the world. Normally, businesses requiring extra capital in the form of acquisitions will sell a variety of instruments, such as bonds or equity, to be offered to the market. The Consumer Goods Industry Index comprises firms active in the consumer goods business in Indonesia. The industry is further classified into: food and beverage, cigarettes, medical devices, cosmetics, home furnishings and accessories. 


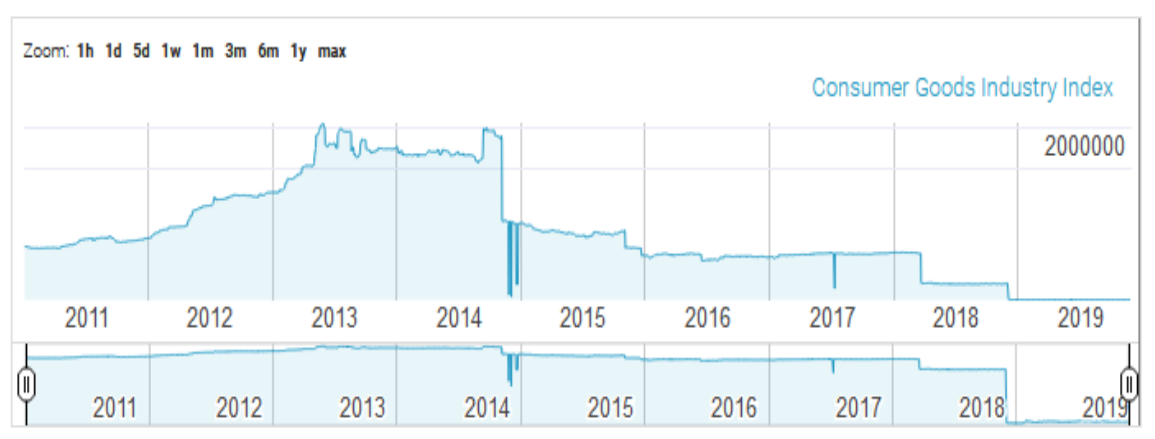

latest update Consumer Goods Industry Index: [345783] - 2014/11/25

Determinant that has a major effect on consumer goods prices include faster wealth creation and infrastructure improvements that are supposed to improve the delivery of consumer products. The medium-income demographic is currently increasing in size and is projected to almost double 141 million by 2020 . This goes in hand with rising spending ability, building a new foundation and establishing high earning prospects throughout the consumer goods market. (https://www.cekindo.com/sectors/consumer-goods-in-indonesia ).

The sustainability of the business is often measured by the valuation of the company. In other terms, the organization must be willing to raise the net profit of the business. High profitability would draw investors and high profitability will contribute to a rise in business valuation. (Aprillia, 2017) Profitability in this study is presented by Return on Assets (ROA). ROA is a measure that calculates the capacity of the business to earn net profits to distribute capital to stakeholders.

Among the many companies that have gone public and listed on the Indonesia Stock Exchange (BEI), one is a manufacturing company, engaging in basic industrial and chemical sector, which represents the elements used in everyday life. In other words, almost all products of daily life are products of basic industrial and chemical companies. For example, the cultivation of plants and animals requires chemical fertilizers such as feed (animal feed), insecticides and pesticides. A wide range of building materials and construction materials are chemically produced, such as metals, cement, lime, ceramics, plastics, and paints. Clothing materials use synthetic fibers and dyes. Transportation depends on the availability of gasoline and similar fuels. Written form of communication uses paper and printing ink, whereas electronic communications require chemically treated insulators and conductors. Public health is maintained with medicines and pharmaceutical ingredients, soaps and detergents, insecticides, and disinfectants, which are classified as chemical products. In the coming years, Indonesia's basic and chemical industries are expected to develop at a steady pace. (industrial development in Indonesia in 2012).

\section{THEORETICAL BACKGROUND}

\subsection{CURRENT RATIO}

According to Hery (2015:166), Liquidity ratio (LR) defines the willingness of a business to service its short-term obligations as it is due. According to Rambe.et.,al.,(2015:49), LR reflects the capacity of a corporation to reimburse its short-term debt commitments in comparison to overall capital and capital assets with short-term obligations, which can be used to measure its liquidity. According to Hantono (2018), the current ratio (CR) indicates the ability of current assets in covering the current liabilities. The stronger the distinction of current assets and total liabilities, the higher the company's capacity to fund short-term liabilities. The low current ratio usually indicates the occurrence of problems in liquidation. However, the overly high current ratio is not a good sign as well, because it shows the number of unemployed funds which could reduce the profitability of companies. CR is used to calculate the capacity of a business to satisfy short-term commitments, ensuring that all existing assets are translated into revenue. The indicator used to calculate the current ratio is through a formula, as follows:

$$
\text { Current Ratio }=\frac{\text { Current Assets }}{\text { Current Liabilities }}
$$




\subsection{DEBT TO EQUITY RATIO (DER)}

DER is the key financial ratio used to determine the financial condition of the organization. This calculation is also an indicator of the willingness of a corporation to pay off its commitments. DER is an important ratio to note when checking the financial health of a company. The rise in the ratio shows that the business was funded by borrowers (lenders) instead of its own financial capital, which may be a very risky development. Lenders and borrowers typically favor a low debt-to-equity level owing to higher interest security if the sector of the entity involved decreases. Thus, a corporation with a large debt to Equity Ratio will not be willing to recover extra resources with a credit of another entity. (Kho, 2017). DER is a measure that used compare loans with equity, and is helpful in calculating the sum of funds given by the purchaser (creditor) to the owner of a business. In other words, the object of this ratio is to understand that any rupiah of its capital is used as leverage for debts (Kasmir, 2010).

According to Murhadi (2013:57), formula of DER is obtained by:

Debt to Equity Ratio $=\frac{\text { Total Debt }}{\text { Total Equity }}$

\subsection{SALES GROWTH (SG)}

According to Kasmir (2012:107), The growth ratio is a measure that defines the corporation's capacity to sustain its competitive place in the midst of economic growth as well as the corporate market. According to Harahap (2015:309), the growth ratio indicates the cumulative growth in business reports throughout the year. According to Fahmi (2016:82), The growth ratio is an indicator that tests the capacity of the business to sustain its place in the market and economic progress in general. According to Harahap (2015:309), the formula for sales growth formula:

Sales Growth $=\frac{\text { This year sales }- \text { Last year sales }}{\text { Last year sales }}$

\subsection{RETURN ON ASSETS (ROA)}

Tandelilin (2010:372) state that, ROA describes how the assets of a company generate profits. According to Hanafi and Halim (2012:81), The growth ratio is an indicator that tests the capacity of the business to sustain its place in the market and economic progress in general. According to Halim and Supomo (2009:151), ROA can be used to measure the profitability of each company production. This variable is very useful to control and is beneficial for strategic planning. Besides, ROA can be restrained by the overall efficiency of capital use, which is sensitive to anything affecting the financial condition of the company. According to Sartono (2010:113), ROA shows the ability of a company to make profits from the assets used. The following is the formula of ROA:

$\mathrm{ROA}=\frac{\text { Earning After Tax }}{\text { Total Assets }}$

Current ratio Towards Profitability- The interaction between liquidity and profitability; as explained by Lartey V., et al. (2013), is There had been a poor beneficial relationship between liquidity and profitability of listed banks in Ghana. According to Madushanka and Jathurika (2019), The study attempts to include a suggestion to manufacturing companies in Sri Lanka who pay more heed to liquidity ratios although they have a direct effect on the viability of enterprises. According to Sartono (2010:116), if the present level were larger, the capacity of the organization to satisfy short-term commitments will therefore be better. According to Rahmawati (2009), The current ratio has a major negative influence on the ROA. A detrimental relationship exists when a company has a higher current ratio implies that the firm has a higher current asset valuation since the funds are further committed to current assets. 
The business would miss its ability to make further profits, because rather than spending the resources to make more profit, the money is allocated to satisfy the liquidity of the organization.

DER Towards Profitability- According to Mulyawan (2015:247), companies with a strong degree of profitability appear to have a lower leverage level. According to Hery (2017:301), the greater the debt-to-equity level means that the volume of owner's resources utilized as debt leverage is larger. According to Sumarsan (2013:47), the higher the debt ratio means that the company would use more money from the creditor to generate profits. According to Rahmawati (2009), DER has a major negative impact on the ROA. The bad relationship is that a company with a higher current ratio means that the firm has a higher current asset valuation, although the funds are further committed to current assets. The business would miss its ability to make more profit, since instead of spending the funds to make more profit, the money is used for the liquidity of the organization.

Sales Growth Towards Profitability- Suriadi (2013), describes the revenue development ratio of a sales growth of the business year to year. If revenues were to increase, the sales growth level would also improve. This influences the company's financial efficiency, where the greater the revenue growth percentage, the higher the profit margin will also rise. Penrose (2004), it claimed that there is an inverse association between present firm development and potential profitability. Mueller (1997) discusses the connection between development and profitability, that concentrated on the System, Behavior and Efficiency (SCP) model, based on organizational development philosophy and corporate performance.

\section{EMPIRICAL ANALYSIS}

\subsection{RESEARCH DESIGN}

In this analysis, the methodological method consists of a descriptive statistical association. Correlational analytical approach is assumed to be relevant to this research since the aim of this research is to include an example of the variable stock market being studied, in the context of a correlation, and to figure out whether or not there is a connection between the variables, how similar the relationship is and how important the relationship is.

\subsection{VARIABLE MEASURE}

\section{Current Ratio}

CR is used to measure the ability of company to meet the short-term obligations, assuming that all current assets convert into cash. The indicator used to calculate the current ratio is by a formula, as follows:

$$
\text { Current Ratio }=\frac{\text { Current Assets }}{\text { Current Liabilities }}
$$

\section{Debt to Equity Ratio}

According to Murhadi (2013:57), DER is obtained by:

Debt to Equity Ratio $=\frac{\text { Total Debt }}{\text { Total Equity }}$

\section{Sales Growth}

According to Harahap (2015:309), SG formula is:

Sales Growth $=\frac{\text { This year sales }- \text { Last year sales }}{\text { Last year sales }}$

\section{Return on Assets}

According to Sartono (2010:113), ROA shows the ability of a company to make profits from the assets used. The following is the formula of ROA: 
The Effect of Current Ratio, Debt to Equity, Sales Growth Towards Return on Asset at Consumer Good Companies Listed in Stock Exchange

$$
\text { ROA }=\frac{\text { Earning After Tax }}{\text { Total Assets }}
$$

\subsection{POPULATION AND SAMPLE}

The collecting data methodology used in this research is a reporting study. According to Sugiyono (2011: 240), documentation is the gathering of evidence through analyzing records in the form of text, pictures or monumental work. For this report, data collection was collected from the financial reports of consumer products firms listed on the Stock Market between 2012 and 2016, which were released on www.idx.co.id. The data forms and references used in this analysis are secondary data. Secondary details were extracted information obtained from the income statement of consumer products firms published on the Indonesian Stock Exchange from 2012 to 2016, which are published on www.idx.co.id.

According to Sugiyono (2011: 80), Population is an area of generalizability composed of artifacts or topics that have those properties and features set out by the investigators to be analyzed and to make conclusions. The population used in this analysis is the consumer goods firms listed on the Indonesian Stock Exchange for the period 2012-2016, with a total of 40 businesses. The sampling methodology used is the process used for the function of sampling. According to Sugiyono (2011: 85), purposive sampling is a method for the determination of samples for some requirements. Table 1 provides a sample of this analysis with the following parameters.:

Table 1: Purposive Sampling Indonesia Stock Exchange for the period 2012-2016.

\begin{tabular}{|c|c|c|}
\hline No & Criteria & Firms \\
\hline 1 & Consumer goods companies listed & 40 \\
\hline 2 & Consumer goods companies doesn't publish financial reports & -10 \\
\hline 3 & Consumer goods companies that have negative cash flows & -6 \\
\hline \multicolumn{2}{|c|}{ Total Sample } & 24 \\
\hline
\end{tabular}

\subsection{RESEARCH MODEL}

To assess the influence of independent variables and dependent variables, a multivariate regression technique is used to calculate the extent of the interaction and the impact of predictor factors wherein 3 (three) or even more $\left(\mathrm{X}_{1}, \mathrm{X}_{2}, \mathrm{X}_{3}\right)$ variables are evaluated against the dependent variable $(\mathrm{Y})$ with the corresponding formulas:

$Y=\alpha+\beta_{1} X_{1}+\beta_{2} X_{2}+\beta_{3} X_{3}+\varepsilon$

where $Y$ is Profitability, $\alpha$ is constant, $\beta$ is regression coefficient of each independent variables, $X_{1}=$ Current ratio, $\mathrm{X}_{2}=\mathrm{DER}, \mathrm{X}_{3}=$ Sales Growth and $\varepsilon$ is percentage error (0.05).

\section{RESULTS AND ANALYSIS}

\subsection{STATISTIC DESCRIPTIVE}

The survey in this analysis consisted of 24 organizations with a testing duration from 2012 to 2016 in order to collect as many as 120 research results. Table 2 shows the data analysis findings for informative statistics.

Table 2: Summary of Descriptive Statistics

\begin{tabular}{|c|c|c|c|c|c|}
\hline & $\mathrm{N}$ & Minimum & Maximum & Mean & Std.Deviation \\
\hline $\mathrm{CR}$ & 120 & .35 & 9.97 & 2.7401 & 1.57805 \\
\hline DER & 120 & .15 & 1.71 & .6881 & .39048 \\
\hline DER & 120 & -.24 & 1.25 & .1336 & .17123 \\
\hline ROA & 120 & -.02 & 0.62 & .1233 & .10391 \\
\hline Valid & 120 & & & & \\
\hline
\end{tabular}

Source: Data Collection Performance 
Normality test- The purpose of the conformity test is to test if the latent independent factor has a direct current in the regression model. The findings of the test of normality may be in the context of the Kolmogorov-Smirnov numerical chart. Throughout this experiment, the criteria used in judgment are: (1) if the relevance output is higher than 0.05 , then the information is typically distributed; and (2) if the significant level is less than 0.05 , therefore the data is not normally distributed. Table 3 gives a description of the effects of the normality test utilizing KolmogorovSmirnov.

Table 3: The results of the normality test using the Kolmogorov-Smirnov test

\begin{tabular}{|c|c|c|}
\hline & $\mathrm{N}$ & 105 \\
\hline Normal Parameters ${ }^{\mathrm{a}, \mathrm{b}}$ & Mean & .0000000 \\
\hline & Std. Deviation & .69181160 \\
\hline Most Extreme Differences & Absolute & .115 \\
\hline & Positive & .093 \\
\hline & Negative & -.115 \\
\hline & Test Statistic & .115 \\
\hline Asyr & np. Sig. (2-tailed) & $.002^{\mathrm{c}}$ \\
\hline Monte Carlo Sig. (2-tailed) & Sig. & $.112^{\mathrm{d}}$ \\
\hline & 99\% Confidence Interval Lower Bound & .104 \\
\hline & Upper Bound & .120 \\
\hline Test distribution is Norma & & \\
\hline Calculated from data.b & & \\
\hline Lilliefors Significance Corr & ection.c & \\
\hline
\end{tabular}

The results of the normality test using Kolmogrof-Smirnov statistics indicate that the variables of current ratio $\left(\mathrm{X}_{1}\right)$, debt to equity ratio $\left(\mathrm{X}_{2}\right)$, Sales Growth $\left(\mathrm{X}_{3}\right)$ and return on assets $(\mathrm{Y})$ have a significant value [Sig. (2-tailed)].112. The result shows $.112>0.05$ which means that the data of all variables in this study are normally distributed.

Multicollinearity test. The object of the Multicollinearity Test is to test if there is a connection between independence variables in the model. There must be no association between predictor factors in a successful regression model. Assessing whether or not there is a multi-collinearity question can be obtained by injecting at the Variance Inflation Factor (VIP) among predictor factors. The cut-off value widely used to denote the existence of multicollinearity is: (1) tolerance value 0.10 ; or (2) VIP value 10 . Table 4 summarizes the findings of the multicollinearity evaluation of this sample

Table 4: Multicollinearity Test

\begin{tabular}{|c|c|c|}
\hline & \multicolumn{2}{|c|}{ Colliearity Statistics } \\
\hline Variables & Tolerance & VIF \\
\hline Constant & & \\
\hline CR & .630 & 1.587 \\
\hline DER & .614 & 1.629 \\
\hline SG & .937 & 1.067 \\
\hline
\end{tabular}

Source: Results of Data Processing

Test findings reveal that the observed value of the factors: CR (X1), DER (X2) and SG (X3) is greater than 0.10. It may also be inferred that there is no multicollinearity in this study. The VIF values obtained for CR (X1), DER (X2) and SG (X3) are all lower than 10 and this implies there is no multicollinearity between independent variables.

Autocorrelation test. This research uses the Durbin-Watson procedure to test for autocorrelation. The DurbinWatson statistic can be used to determine not whether residual data exists at variance. The Durbin-Watson test 
The Effect of Current Ratio, Debt to Equity, Sales Growth Towards Return on Asset at Consumer Good Companies Listed in Stock Exchange

parameters are as follows: (a) if the DW-value <-2 implies there is a significant autocorrelation; (b) if the DW-value is between- 2 and +2 , there really is no autocorrelation; and (c) if the DW-value $>+2$ means that there is still a negative autocorrelation. Table 5 displays the effects of the autocorrelation test of this analysis. Centered on table 5 above, it can be shown that the DW-value of the Durbin-Watson test is 0.738 , which is between- 2 and $+2(-2<0.998$ $<+2$ ). This indicates there is no autocorrelation of the regression model.

Table 5: A Summary of Results of the Durbin-Watson Autocorrelation Test R

\begin{tabular}{|c|c|c|c|c|}
\hline $\mathrm{R}$ & R Square & Adjusted R Square & Std. Error of the Estimate & Durbin-Watson \\
\hline $.425^{\mathrm{a}}$ & .180 & .159 & 0.9529 & .998 \\
\hline
\end{tabular}

Source: Results of Data Processing

Heteroscedasticity test. The heteroscedasticity test is done to assess if there are variations in the linear regression between residues of one experiment then another. The Glejser test can detect the existence or lack of heteroscedasticity in this analysis. Table 6 reveals that the values of importance for the factors CR $\left(\mathrm{X}_{1}\right)$ and DER $\left(\mathrm{X}_{2}\right)$ and $\mathrm{SG}\left(\mathrm{X}_{3}\right)$ are greater than 0.05 .

Table 6: Heteroscedasticity Test Results by the Glejser Method

\begin{tabular}{|c|c|c|c|c|c|}
\hline Variables & \multicolumn{2}{|c|}{$\begin{array}{c}\text { Unstandardized } \\
\text { Coefficients }\end{array}$} & $\begin{array}{c}\text { Standardized } \\
\text { Coefficients }\end{array}$ & \multirow{2}{*}{ Sig. } & \\
\cline { 2 - 5 } & Beta & Std.Error & Beta & & \\
\hline Constant & .052 & .027 & & 1.951 & .054 \\
\hline CR & .006 & .005 & .135 & 1.174 & .243 \\
\hline DER & -.013 & .021 & -071 & -.609 & .554 \\
\hline SG & .016 & .039 & .039 & 0.059 & .679 \\
\hline
\end{tabular}

Source: Results of Data Processing

Coefficient of determination. The coefficient of determination is meant to assess the effectiveness of the proposed model to describe the dependent variable. If the variance of decision $\left(\mathrm{R}^{2}\right)$ is greater than or closer to 1 , the capacity of the independent variable $(\mathrm{X})$ is high enough to justify the dependent variable $(\mathrm{Y})$. The consequence of the decision coefficient for the hypothesis in this analysis is shown in Table 7. The effects of the test of the coefficient of determination are equivalent to or equal to $18 \%$ of the modified $\mathrm{R}$ Square $\left(\mathrm{R}^{2}\right)$ meaning. This means that discrete variables affect asset returns by as many as 18 per cent and the other $72 \%$ influence both these factors.

Table 7: Coefficient of Determination for the Hypothesis

\begin{tabular}{|l|l|l|l|}
\hline $\mathrm{R}$ & R Square & Adjusted R Square & Std. Error of the Estimate \\
\hline $.425^{\mathrm{a}}$ & .180 & .159 & .09529 \\
\hline
\end{tabular}

Source: Results of Data Processing

Simultaneous testing of hypotheses (F test). The F test is being used to demonstrate if any of the independent variables also have simultaneous effect on the dependent variable. To evaluate this statement, the F-Statistic is used for the corresponding decision-making parameters:

1) if $\mathrm{F}_{\text {counted }}>\mathrm{Ftable}$ or sig. $<0.05$, then $\mathrm{H} 0$ is rejected and $\mathrm{Ha}$ is accepted; and

2) if $\mathrm{F}_{\text {counted }} \leq \mathrm{Ftable}$ or sig. $\geq 0.05$, then $\mathrm{Ha}$ is rejected and $\mathrm{H}_{0}$ is accepted. The hypotheses to be tested in this case are:

H0: CR, DER, SG do not have an effect ROA in consumer goods companies listed on the Indonesia Stock Exchange for the period 2012-2016.

Ha: CR, DER, SG have an effect ROA in consumer goods companies listed on the Indonesia Stock Exchange for the period 2012-2016. 
Hantono

Table 8: Summary of F test Results

\begin{tabular}{|c|c|c|c|c|c|}
\hline & Sum of squares & Df & Mean square & F & Sig. \\
\hline Regression & .232 & 3 & .077 & 8.503 & $.000^{\mathrm{b}}$ \\
\hline Residual & 1.053 & 116 & .009 & & \\
\hline Total & 1.285 & 119 & & & \\
\hline
\end{tabular}

Source: Results of Data Processing

The table above indicates that the meaning of $\mathrm{F}_{\text {counted }}$ is 8.503 and $\mathrm{F}_{\text {table }}$ is 2.45 , or $\mathrm{F}_{\text {counted }}<\mathrm{F}_{\text {table. This implies that }}$ $\mathrm{HO}$ is approved and that Ha is refused. In summary, independent variables (CR, DER and SG) have a major simultaneous impact on the dependent variable (ROA) in consumer goods companies reported on the Indonesian Stock Exchange for the duration 2012-2016.

The model- Multiple linear regression methodology is used to assess the hypothesis of this report. The regression analysis used are indeed the following:

Table 9: Regression Model

\begin{tabular}{|c|c|c|c|c|c|}
\hline Variables & \multicolumn{2}{|c|}{$\begin{array}{c}\text { Unstandardized } \\
\text { Coefficients }\end{array}$} & $\begin{array}{c}\text { Standardized } \\
\text { Coefficients }\end{array}$ & $\mathrm{t}$ & Sig. \\
\cline { 2 - 4 } & Beta & Std.Error & Beta & & \\
\hline Constant & .125 & .036 & & 3.476 & .001 \\
\hline CR & .014 & .007 & .214 & 2.016 & .046 \\
\hline DER & -.073 & .029 & -.274 & -2.550 & .012 \\
\hline SG & .076 & .053 & .126 & 1.450 & .150 \\
\hline
\end{tabular}

Source: Results of Data Processing

$\mathrm{ROA}=.125+.014 \mathrm{CR}-0.073 \mathrm{DER}+.076 \mathrm{SG}$

The definitions of the multiple regression equation are given below:

1) The value of a is .125, meaning that if the variables of CR, DER, and SG are considered constant, ROA is .125.

2) The coefficient value of the CR is .014. This shows that for every 1 unit increase in CR, the ROA will decrease by 014 .

3) The coefficient of DER is -.0073. This shows that for every 1 unit increase in DER, ROA increases by -.0073.

4) The coefficient of SG is.076. This shows that for every 1 unit increase in SG, ROA decreases by .076.

The $\mathbf{t}$ test is used to demonstrate the effect of an independent variable on the dependent variable. This test is performed by contrasting the measures of importance with the following requirements:

1) If ttable $\leq$ tcounted $\leq+$ ttable or Sig. $\geq=0.05$, then $\mathrm{H}_{\mathrm{a}}$ is rejected and $\mathrm{Ho}$ is accepted.

2) If tcounted $>$ table or tcounted $\leq$ ttable or Sig. $<=0.05$, then $\mathrm{H}_{0}$ is rejected and $\mathrm{Ha}$ is accepted.

The hypotheses to be tested in this case are:

H0: CR, DER and SG, do not have the partial effect on ROA in consumer goods companies listed on the Indonesia Stock Exchange for the period 2012-2016.

Ha: CR, DER and SG, have the partial effect ROA in consumer goods companies listed on the Indonesia Stock Exchange for the period 2012-2016.

Table 10: The results summary of the t test

\begin{tabular}{|c|c|c|c|c|c|}
\hline Variables & \multicolumn{2}{|c|}{$\begin{array}{c}\text { Unstandardized } \\
\text { Coefficients }\end{array}$} & $\begin{array}{c}\text { Standardized } \\
\text { Coefficients }\end{array}$ & $\mathrm{t}$ & Sig. \\
\cline { 2 - 4 } & Beta & Std.Error & Beta & & \\
\hline Constant & .125 & .036 & & 3.476 & .001 \\
\hline CR & .014 & .007 & .214 & 2.016 & .046 \\
\hline
\end{tabular}


The Effect of Current Ratio, Debt to Equity, Sales Growth Towards Return on Asset at Consumer Good Companies Listed in Stock Exchange

\begin{tabular}{|c|c|c|c|c|c|}
\hline DER & -.073 & .029 & -.274 & -2.550 & .012 \\
\hline SG & .076 & .053 & .126 & 1.450 & .150 \\
\hline
\end{tabular}

Source: Results of Data Processing

CR to ROA- CR has a tcounted of $2.016<1.979$ and a significance value of.046 $<0.05$, then $\mathrm{Ho}$ is accepted, meaning that the CR has a major partial impact on ROA in consumer goods firms listed on the Indonesian Stock Exchange for the duration 2012-2016. The findings of the present analysis are consistent with the results of previous studies by Madushanka and Jathurika (2019). Overall, this study can provide a suggestion to companies in sri Lanka who pay more heed to liquidity ratios since they have a direct effect on the profitability of firms. According to Sartono (2010:116), the stronger the CR means that the capacity of the organization to fulfill short-term commitments is stronger. This result isn't supported by Rahmawati (2009) finding that the CR has a negative significant effect on the ROA. A detrimental association exists when a company with a higher CR implies that the company has a greater return in existing assets, since the funds are further committed to current assets. The business would miss its ability to make more profit, since instead of spending the funds to make more profit, the money is used for the liquidity of the organization.

DER to ROA- The DER has a tcounted of - $2.550<1.979$ and a significance value of $.012>0.05$, then Ho is accepted. This indicates that the DER does not have a major partial impact on ROA in consumer goods firms listed on the Indonesian Stock Exchange for the duration 2012-2016. The findings of the present analysis are compatible with the results of previous studies. According to Mulyawan (2015:247), When businesses with a strong degree of profitability appear to have a low level of debt. According to Hery (2017:301), The larger the DER, the lower the sum of the owner's resources that may be used as leverage debt. According to Sumarsan (2013:47), The bigger the DER, the most creditor capital the firm uses to create income. This finding is supported by Rahmawati (2009) that DER has a major negative impact on the ROA. The bad relationship is that a company with a higher CR means that the firm has a higher current asset valuation, since the funds are further committed to current assets. The business would miss its ability to make more profit, since instead of spending the funds to make more profit, the money is used for the liquidity of the organization.

SG to ROA- SG has a $\mathrm{t}_{\text {counted }}$ of $1.450<1.976$ and a significance value of $.012>0.05$, then $\mathrm{Ho}$ is accepted. This indicates that SG does not have a major partial impact on ROA in consumer goods firms listed on the Indonesian Stock Exchange for the duration 2012-2016. This result isn't supported by Suriadi (2013), That explains the SG ratio of the SG of a business year to year. The SG ratio would also rise as sales improve. This influences the financial efficiency of the firm, where the greater the SG ratio, the higher the company's benefit.

\section{CONCLUSION, IMPLICATION AND SUGGESTION}

\subsection{CONCLUSION}

On the basis of information and findings, this can be summarized as follows:

1) CR, DER and SG have a major synchronized influence on the dependent variable (ROA) in consumer goods firms listed on the Indonesian Stock Exchange for the period 2012-2016.

2) CR has a major partial impact on ROA in consumer goods firms listed on the Indonesian Stock Exchange for the duration 2012-2016.

3) DER has a major partial impact on ROA in consumer goods firms listed on the Indonesian Stock Exchange for the duration 2012-2016.

4) SG doesn't have a significant partial effect on ROA in consumer goods companies listed on the Indonesia Stock Exchange for the period 2012-2016.

5) The value of Adjusted $R^{2}$ of 0.180 , which means a variation of CR, DER and SG, have an $18 \%$ effect on ROA in consumer goods companies listed on the Indonesia Stock Exchange for the period 2012-2016. 


\subsection{IMPLICATION} follows:

The results of this study are intended for consumers, businesses, scholars, people and potential research as

1) To Investor

On the basis of the study, it is advised that details on the business profile be sought in anticipation so that they might check out the financial performance before purchasing. This detail can be conveniently accessed from the www.idx.co.id website.

2) To companies

The test outcome should be seen as supplementary details for businesses to find out regarding CR, DER and SG in the initiative of ROA.

3) To academics

The findings of this research may have an effect on the creation of economics, notably in accounting.

4) To future research

Additional variables may be introduced to establish additional hypotheses.

\subsection{SUGGESTION}

From the findings of the review and debate, the recommendation is as follows:

1) Investors are expected to be attracted to invest in future opportunities so that profitability would directly increase.

2) Company is recommended to improve level of management effectiveness in limited resources so that there would be improvement in profitability and liquidity of the company.

\section{SOURCES OF FUNDING}

This research received no specific grant from any funding agency in the public, commercial, or not-for-profit sectors.

\section{CONFLICT OF INTEREST}

The author have declared that no competing interests exist.

\section{ACKNOWLEDGMENT}

None.

\section{REFERENCES}

[1] Erlina., Rambe, O. S., \& Rasdianto. (2015). Akuntansi Keuangan Daerah Berbasis Akrual. Jakarta: Salemba Empat.

[2] Fahmi, I. (2016). Teori dan Teknik Pengambilan Keputusan. Jakarta: Raja Grafindo Persada.

[3] Halim, A. \& Supomo (2009). Akuntansi Manajemen. Yogyakarta: BPFE, 151.

[4] Hanafi, M. \& Halim, A. (2012). Analisis Laporan Keuangan. Yogyakarta: UPP STIM YKPN, 79-81.

[5] Harahap, S. S. (2015). Analisis Kritis atas Laporan Keuangan. Jakarta: Rajawali Pers.

[6] Hantono. (2018). Konsep Analisa Laporan Keuangan Dengan Pendekatan Rasio dan SPSS. Yogyakarta: Deepublis Publisher.

[7] Lartey V, Antwi1 S, Boadi E. (2013). The Relationship between Liquidity and Profitability of Listed Banks in Ghana. International Journal of Business and Social Science, Vol. 4 No. 3; March 2013.

[8] Kho, B. (2017, October 4). Pengertian Debt to Equity Ratio (DER) dan Rumus DER. Retrieved May 2019, from Ilmu Manajemen Industri: https://ilmumanajemenindustri.com/pengertian-debt-to-equity-ratio-der-danrumus-der/ 
[9] Madushanka, K.H. I and M.Jatthurika. (2019). The Impact of Liquidity Ratios on Profitability (With special reference to Listed Manufacturing Companies in Sri Lanka). International Research Journal of Advanced Engineering and Science.

[10] Kasmir. (2010). Pengantar Manajemen Keuangan. Bandung: PT Raja Grafindo Persada.

[11] __ _ (2012). Analisis Laporan Keuangan. Jakarta: PT. Raja Grafindo Persada.

[12] Kor, Y.Y.; Mahoney, J.T. Edith penrose's (1959) Contributions to The Resource-Based View of Strategic Management. J. Manag. Stud. 2004, 41, 183-191.

[13] Mueller, D.C. (1977). The Persistence of Profits Above the Norm Economica. 44, 369-380.

[14] Rahmawati, Fitri Linda. (2009). Pengaruh Current Ratio, Inventory Turnover, dan Debt to Equity Ratio Terhadap Return on Asset (Studi pada Perusahaan Food and Beverage yang Listing di BEI Tahun 2007 2009). Jurnal Universitas Negeri Malang.

[15] Suriadi, Laurensky. (2013). Pengaruh Sales Growth, Debt to Equity Ratio, dan Deviden Payout Ratio Terhadap Return on Asset. Jurnal Bisnis dan Akuntansi. Jakarta: Universitas Esa Unggul.

[16] Tandelilin, Eduardus. 2010. Portofolio dan Investasi Teori dan Aplikasi. Edisi pertama. Yogyakarta: Kanisius, $366,372-374$. 